\title{
Article \\ Characterization of the HCN Interaction Partner TRIP8b/PEX5R in the Intracardiac Nervous System of TRIP8b-Deficient and Wild-Type Mice
}

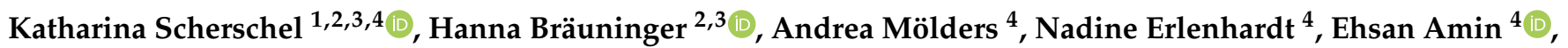 \\ Christiane Jungen ${ }^{2,3,4,5}{ }^{(D)}$, Ulrike Pape ${ }^{2}$, Diana Lindner ${ }^{2,3}{ }^{\mathbb{D}}$, Dane M. Chetkovich ${ }^{6}$, Nikolaj Klöcker ${ }^{4}$ \\ and Christian Meyer 1,2,3,4,*
}

\section{check for} updates

Citation: Scherschel, K.; Bräuninger, H.; Mölders, A.; Erlenhardt, N.; Amin, E.; Jungen, C.; Pape, U.; Lindner, D.; Chetkovich, D.M.; Klöcker, N.; et al. Characterization of the $\mathrm{HCN}$ Interaction Partner TRIP8b/PEX5R in the Intracardiac Nervous System of TRIP8b-Deficient and Wild-Type Mice. Int. J. Mol. Sci. 2021, 22, 4772. https://doi.org/10.3390/ijms22094772

Academic Editor: Brian P. Delisle

Received: 31 March 2021

Accepted: 28 April 2021

Published: 30 April 2021

Publisher's Note: MDPI stays neutra with regard to jurisdictional claims in published maps and institutional affiliations.

Copyright: (c) 2021 by the authors Licensee MDPI, Basel, Switzerland. This article is an open access article distributed under the terms and conditions of the Creative Commons Attribution (CC BY) license (https:/ / creativecommons.org/licenses/by/ $4.0 /)$.
1 Division of Cardiology, EVK Düsseldorf, cNEP, Cardiac Neuro- and Electrophysiology Research Consortium, Kirchfeldstrasse 40, 40217 Düsseldorf, Germany; katharina.scherschel@hhu.de

2 Clinic for Cardiology, University Heart \& Vascular Centre, University Hospital Hamburg-Eppendorf, Martinistrasse 52, 20246 Hamburg, Germany; h.braeuninger@uke.de (H.B.); c.jungen@uke.de (C.J.); ulrikepape1@gmail.com (U.P.); d.lindner@uke.de (D.L.)

3 DZHK (German Centre for Cardiovascular Research), Partner Site Hamburg/Kiel/Lübeck, 20246 Hamburg, Germany

4 Institute of Neural and Sensory Physiology, Medical Faculty, Heinrich Heine University Düsseldorf, Universitätsstrasse 1, 40225 Düsseldorf, Germany; andrea.moelders@uni-duesseldorf.de (A.M.); nadine.erlenhardt@hhu.de (N.E.); ehsan.amin@hhu.de (E.A.); nikolaj.kloecker@uni-duesseldorf.de (N.K.)

5 Department of Cardiology, Leiden University Medical Center, 2333 ZA Leiden, The Netherlands

6 Department of Neurology, Vanderbilt University Medical Center, Nashville, TN 37232, USA; dane.m.chetkovich@vumc.org

* Correspondence: c.mey@web.de

Abstract: The tetratricopeptide repeat-containing Rab8b-interacting protein (TRIP8b/PEX5R) is an interaction partner and auxiliary subunit of hyperpolarization-activated cyclic nucleotide-gated $(\mathrm{HCN})$ channels, which are key for rhythm generation in the brain and in the heart. Since TRIP8b is expressed in central neurons but not in cardiomyocytes, the TRIP8b-HCN interaction has been studied intensely in the brain, but is deemed irrelevant in the cardiac conduction system. Still, to date, TRIP8b has not been studied in the intrinsic cardiac nervous system (ICNS), a neuronal network located within epicardial fat pads. In vitro electrophysiological studies revealed that TRIP8bdeficient mouse hearts exhibit increased atrial refractory and atrioventricular nodal refractory periods, compared to hearts of wild-type littermates. Meanwhile, heart rate, sino-nodal recovery time, and ventricular refractory period did not differ between genotypes. Trip $8 \mathrm{~b}$ mRNA was detected in the ICNS by quantitative polymerase chain reaction. RNAscope in situ hybridization confirmed Trip $8 \mathrm{~b}$ localization in neuronal somata and nerve fibers. Additionally, we found a very low amount of mRNAs in the sinus node and atrioventricular node, most likely attributable to the delicate fibers innervating the conduction system. In contrast, TRIP8b protein was not detectable. Our data suggest that TRIP8b in the ICNS may play a role in the modulation of atrial electrophysiology beyond $\mathrm{HCN}$-mediated sino-nodal control of the heart.

Keywords: autonomic nervous system; TRIP8b; HCN channels; cardiac electrophysiology

\section{Introduction}

In the brain and the heart, hyperpolarization-activated cyclic nucleotide-gated (HCN) channels are key for pacemaking [1,2]. The HCN interaction partner tetratricopeptide repeat-containing Rab8b-interacting protein (TRIP8b/PEX5R) is an auxiliary subunit, which affects the gating properties of HCN2 and HCN4, the main isoforms for spontaneous rhythm generation in cardiac pacemaker cells, by limiting cAMP-induced activation [3]. TRIP8b expression is cell- and tissue-restricted: in total, 11 splice forms are described 
in the central nervous system in selected neuronal [4] and glial [5] subpopulations and one in testis [6]. Previous studies have shown that TRIP8b is not expressed in the whole heart [6] or cardiomyocytes [3]. Still, sino-nodal pacemaker cells could be modulated by TRIP8b, as was recently shown with a minimal peptide that recapitulated the gating effect of full-length TRIP8b and was able to prevent cAMP regulation of HCN channels [7].

Cardiac rhythm and electrophysiology are modulated by the autonomic nervous system, which communicates signals from the brainstem to the intrinsic cardiac nervous system (ICNS) $[8,9]$. This complex network of different neurons and glial cells is located in atrial fat tissue and further relays signals via an extensive network of nerve fibers to the sinus node, atrioventricular (AV) node, and to the atrial and ventricular working myocardium. Even though cardiac neurons make up only a tiny amount of cells in the heart (approx. 1000 cells in the mouse [10], 43,000 in the human heart [11]), they modulate every heartbeat $[8,12]$, and their molecular understanding is of high interest. The HCN current $I_{\mathrm{f}}$ has been recorded in the ICNS of guinea pigs [13,14], and action potential firing elicited by HCN2 was shown in other peripheral neurons [15]. HCN channels were shown to be present in parasympathetic [16], sympathetic [17], and sensory [15,18] ganglia of the autonomic nervous system. Thus, we hypothesized that the HCN channel auxiliary subunit TRIP8b is present in cardiac neurons of the ICNS and plays a role in the modulation of cardiac electrophysiology.

Therefore, the goal of this study was to investigate TRIP8b in the murine ICNS using TRIP8b-deficient mice and wild-type littermate controls and perform in-depth expression analyses and in vitro electrophysiological studies. Our experiments reveal changes in atrial electrophysiology of TRIP8b-deficient mice, suggesting a role of TRIP8b in the ICNS beyond HCN-mediated sino-nodal control of the heart.

\section{Results}

2.1. Electrophysiological Recordings from Wild-Type and TRIP8b-Deficient Mouse Heart Preparations

Electrophysiological characterization of TRIP8b-deficient mouse hearts and wild-type littermate controls (exemplary genotyping in Supplementary Figure S1A) was performed employing programmed stimulation in vitro (Figure 1A). Representative tracings are presented in Figure 1B. ARP and AVNRP were increased in TRIP8b-deficient mice (ARP: $24.9 \pm 1.8$ ms wild type $(n=7)$ vs. $32.9 \pm 1.5$ ms knockout $(n=9), p=0.0045$ unpaired $t$-test; AVNRP: $60.0 \pm 3.2 \mathrm{~ms}$ wild type $(n=7)$ vs. $73.2 \pm 2.8$ ms knockout $(n=10), p=0.0075$ unpaired $t$-test), indicating that conduction properties of atrial cardiomyocytes and $\mathrm{AV}$ nodal conduction is affected by the deletion of TRIP8b. In contrast, heart rate at the beginning of the protocol did not differ between the genotypes (heart rate: $524.4 \pm 19.9$ beats per minute $(\mathrm{bpm})$ wild type $(n=9)$ vs. $514.5 \pm 14.02 \mathrm{bpm}$ knockout $(n=11), p=0.6781$ unpaired $t$-test). Additionally, neither SNRT nor rate-corrected SNRT (cSNRT) differed between the genotypes (SNRT\%: $144.3 \pm 12.6$ wild type vs. $128.2 \pm 3.5$ knockout, $p=0.3599$ Mann-Whitney test; cSNRT: $69.8 \pm 19.2$ wild type vs. $59.2 \pm 8.8$ knockout, $p=0.8868$, Mann-Whitney test), indicating no changes affecting the sinus node. WBP and VRP remained unchanged (Supplementary Table S1), indicating no changes in ventricular level in TRIP8b-deficient mice.

Next, we infused the nicotinic antagonist hexamethonium in hearts from TRIP8bdeficient mice to evaluate whether the blockade of ganglionic activity in the ICNS influences cardiac electrophysiological parameters. As described previously in wild-type mice [19], we detected a decrease of AVNRP $(73.2 \pm 2.8 \mathrm{~ms}$ without $(n=6)$ vs. $60.8 \pm 1.0 \mathrm{~ms}$ with hexamethonium $(n=5), p=0.0103$, unpaired $t$-test), WBP $(82.6 \pm 2.2 \mathrm{~ms}$ without vs. $74.8 \pm 1.0 \mathrm{~ms}$ with hexamethonium, $p=0.0330$, unpaired $t$-test) and trends toward reduction of ARP, SNRT\% and WBP (compare Figure 1C and Supplementary Table S1). This indicates that ganglionic activity is not diminished in TRIP8b-deficient mice.

AF was inducible in $3 / 18$ attempts $(16.7 \%)$ in hearts from wild-type animals, while $0 / 21$ stimulations induced AF in TRIP8b-deficient animals $(p=0.051$; Supplementary Figure S1B). 

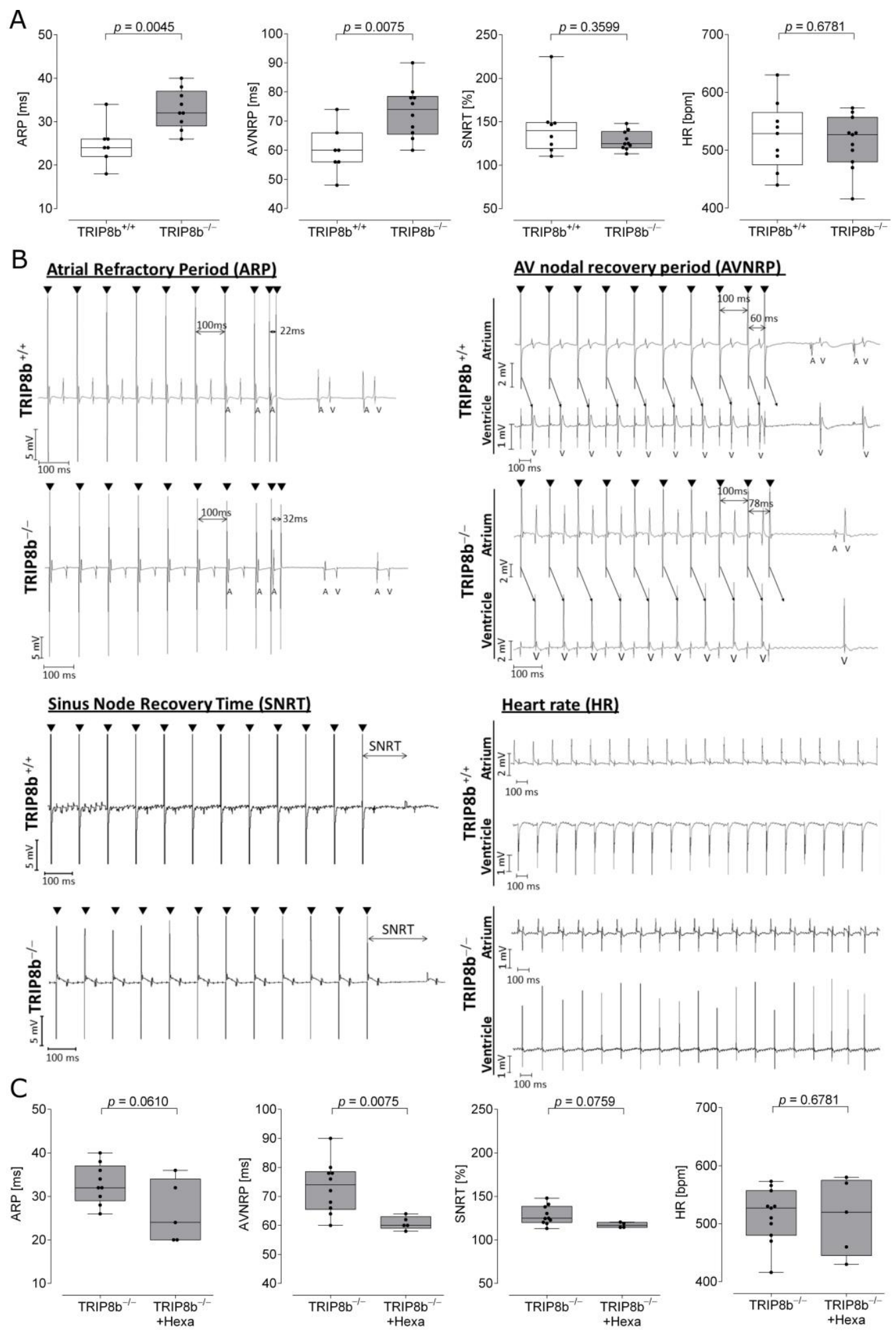

Figure 1. TRIP8b-deficient mice have altered atrial electrophysiology. (A) In vitro electrophysiological measurements from Langendorff-perfused hearts show an increase of atrial refractory period (ARP) and atrioventricular-nodal refractory period (AVNRP) in TRIP8b-deficient mice, without changes in sino-nodal activity (sino-nodal recovery time, SNRT) and heart rate (HR). (B) Representative tracings are shown for wild-type and TRIP8b-deficient mice. A, atrial activity; atrium electrophysiological tracings from the atrium; $\mathrm{V}$, ventricular activity; ventricle electrophysiological tracings from the ventricle; black arrowheads mark atrial or ventricular stimulation. (C) Ganglionic blockade with 0.5 mM hexamethonium leads to a reduction of AVNRP in TRIP8b-deficient mice. Data are presented as box plots (minimum to maximum, $n=5-11$ per genotype) and were compared using an unpaired $t$-test or Mann-Whitney, as appropriate. 


\subsection{Morphological Analyses}

Heart weight to body weight ratio did not differ between wild-type and TRIP8bdeficient mice (Supplementary Figure S1C), indicating that the hearts were neither hypernor hypotrophic. Accordingly, H\&E staining (Supplementary Figure S1D) for morphological assessment showed no obvious structural changes or signs of remodeling in hearts of TRIP8b-deficient animals. Additionally, no indication of fibrosis was detected via picrosirius red staining (Supplementary Figure S1D).

\subsection{Gene Expression Analysis of Trip8b}

Epicardial fat tissue from the atria, which contains cardiac nerves and neurons, was used for the generation of ICNS cDNA. A PCR with primers targeting exon 6/7, the deleted region in TRIP8b-deficient mice [4], was performed and resulted in a $200 \mathrm{bp}$ band, indicating the presence of Trip $8 b \mathrm{mRNA}$ in the ICNS in wild-type mice. As expected, there was no amplification product in knockout tissue (Figure 2A, left panel). Interestingly, quantitative PCR of ICNS cDNA detected exon 8-9, 9-10, and 13-14 of Trip8b in TRIP8bdeficient mice, even though there was a trend of a reduction of mRNA in knockout ICNS cDNA. CT values were exon 8-9: $32.5 \pm 0.53$ wild type vs. $32.84 \pm 0.16$ knockout; exon 9-10: $33.13 \pm 0.44$ wild type vs. $33.73 \pm 0.05$ knockout, exon 13-14: $32.6 \pm 0.48$ wild type vs. $33.43 \pm 0.06$ knockout (compare Figure $2 \mathrm{~A}$, right panel for relative expression normalized to $C d k n 1 b$ ). This indicates the presence of partial Trip $8 b$ transcripts of later exons in knockout mice.

A

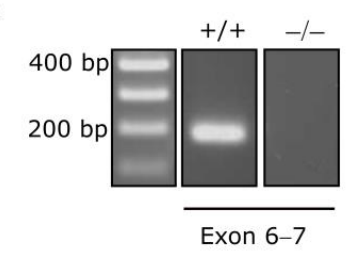

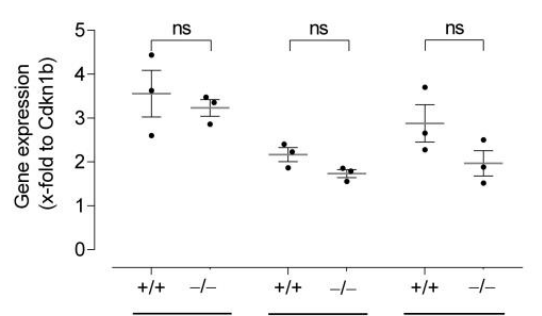

B

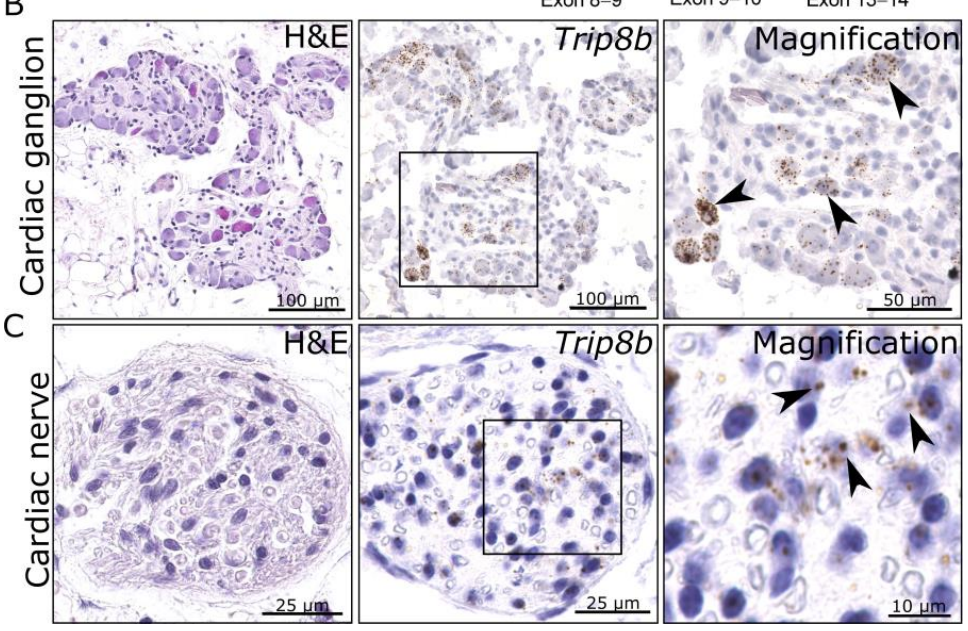

Figure 2. Trip $8 \mathrm{~b}$ mRNA is present in the cardiac nervous system. (A) Exon 6-7 can be amplified in cDNA of ganglia-containing atrial tissue of wild-type but not of TRIP8b-deficient mice (left panel). Quantitative PCR analyses show that exon 8-9, 9-10, and 13-14 of Trip $8 b$ are still detectable in knockout mice. Data (normalized to Cdkn1b) are presented as individual data points with SEM $(n=3$, right panel) and were compared via one-way ANOVA followed by Sidaks' multiple comparison test; ns, not significant. (B) Trip $8 b$ mRNA can be visualized with RNAscope in situ hybridization in neuronal cell bodies of cardiac ganglia. Black arrows in magnifications point to single neurons with Trip $8 b$ mRNAs. (C) Trip $8 b$ mRNA (black arrows) can be visualized with RNAscope in situ hybridization in cardiac nerves of wild-type mice. 
To identify the location of Trip8b-expressing cells, mRNA was visualized via RNAscope in situ hybridizations of whole heart paraffin sections. As hypothesized, mRNA molecules were detectable in neuronal cell bodies within cardiac ganglia (Figure 2B) and cardiac nerves of the ICNS of wild-type animals (Figure 2C). The ICNS serves as a relay station for parasympathetic input from the brain to the sinus node and AV node, as well as the working myocardium [20]. Therefore, we analyzed the sinus node and AV node, identified by expression of Hcn4. We detected solitary Trip $8 \mathrm{~b}$ mRNAs in the sinus node surrounding the sinus node artery (Figure 3A) and the AV node (Figure 3B).
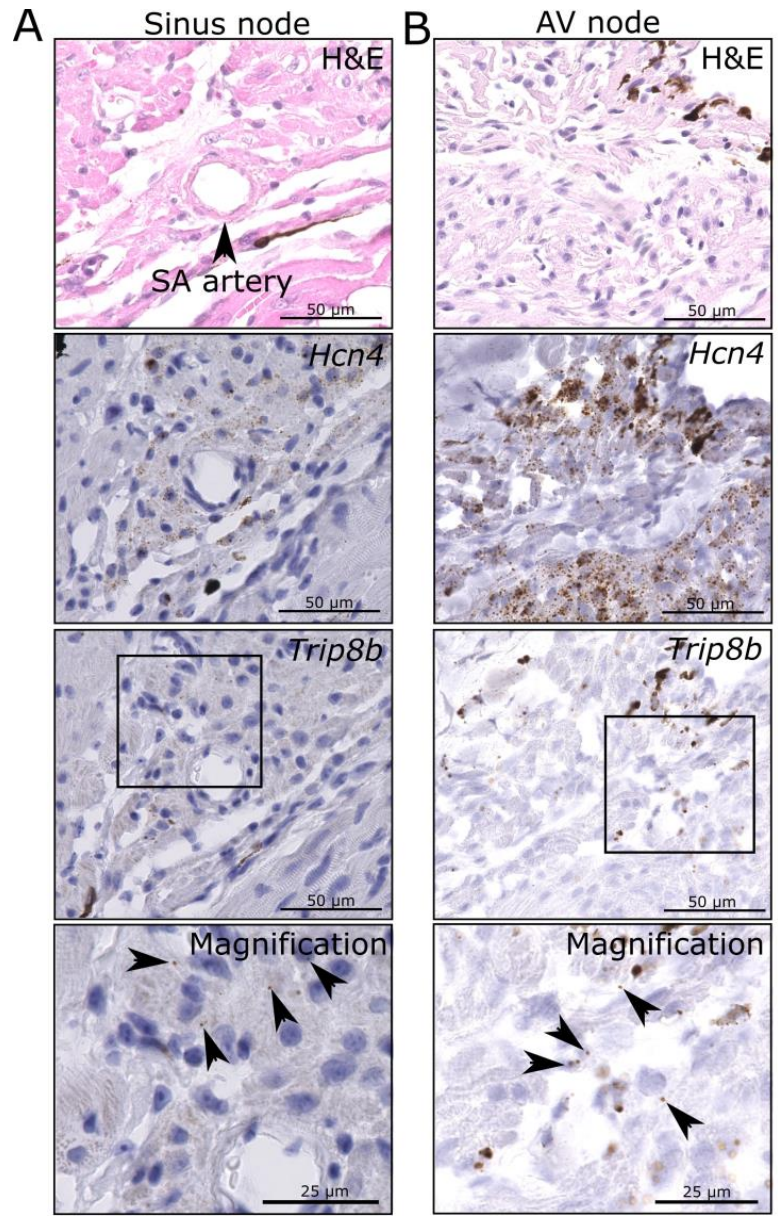

$$
\text { C }
$$
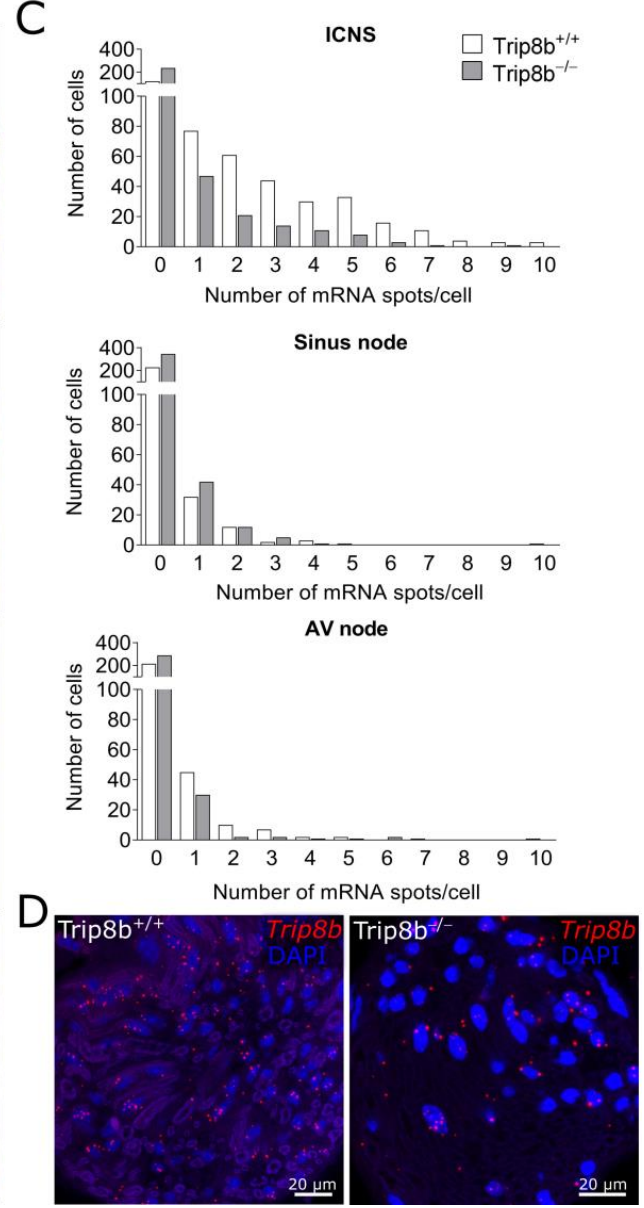

Figure 3. Trip8b mRNAs are detectable in the cardiac conduction system to a lower amount than in the intracardiac nervous system. (A) Sinus node and (B) atrioventricular node (AV node) were identified via hematoxylin and eosin (H\&E) staining and Hcn 4 RNAscope in situ hybridization. Subsequent sections treated with a probe specific for Trip $8 b$ show solitary mRNA spots (black arrows) surrounding the sinus node artery and in the AV node. Nuclei are counterstained with hematoxylin in blue. (C) The histogram shows the distribution of Trip $8 b$ mRNA spots per cell in the intracardiac nervous system (ICNS, nerves, and ganglia), sinus node, and AV node of wild-type and TRIP8b-deficient mice. Overall, 279-404 cells were analyzed for each region of interest per genotype, $n=2-3$ images/genotype. (D) Trip $8 b$ in situ hybridization (red) detects mRNA in wild-type mice but also, to a lower amount, in knockout mice.

Quantification of Trip $8 b$ mRNA in ICNS, sinus node, and AV node was performed on images of fluorescent in situ hybridizations in both genotypes. Data are visualized as a histogram in Figure 3C. In the ICNS, we detected a mean of $2.18 \pm 0.11 \mathrm{mRNA}$ spots per cell vs. $0.73 \pm 0.08 \mathrm{mRNA}$ spots per cell in knockout $(p<0.0001$, Mann-Whitney test; nerve: $n=3$ images/genotype, ganglia: $n=3$ images $/$ wild type, $n=1$ image $/$ knockout). In sinus node, $0.32 \pm 0.06 \mathrm{mRNA}$ spots / cell were detected in wild type vs. $0.21 \pm 0.03$ mRNA spots/cell in knockout ( $p=0.6972$, Mann-Whitney test; $n=2$ images/wild type, $n=3$ images/knockout). In the AV node, $0.43 \pm 0.06$ mRNA spots/cell were present in 
wild type vs. $0.19 \pm 0.04$ mRNA spots/cell in knockout ( $p=0.5859$, Mann-Whitney test, $n=3$ images/genotype). Between 279 and 404 cells were analyzed per region of interest and per genotype. The presence of Trip $8 b$ mRNAs in the ICNS of TRIP8b-deficient mice is presented as exemplary in Figure 3D. This is in line with the results from quantitative PCR, confirming the presence of partial transcripts. The quantification also confirms the visual assessment that more Trip $8 b$ is present in the ICNS than in the conduction system in wild-type mice ( $p<0.0001$, Kruskal-Wallis tests between ICNS, sinus node, and AV node). In the ICNS, $70.1 \%$ of wild-type cells presented at least one Trip $8 b$ mRNA spot (vs. $31.1 \%$ in knockout), in sinus node $18.4 \%$ in wild type (vs. $14.9 \%$ in knockout) and in the AV node $24.3 \%$ in wild type (vs. $11.7 \%$ in knockout). The high percentage of Trip $8 b$ expressing cells in the ICNS, compared to the conduction system, indicates that this is the origin of the phenotype in TRIP8b-deficient mice.

\subsection{Protein Expression Analysis of TRIP8b}

Protein expression of TRIP8b was analyzed via immunoblotting. As expected, a double band of approx. $72 \mathrm{kDa}$ was detectable in wild-type brain lysates [4] with $10 \mu \mathrm{g}$ and $2.5 \mu \mathrm{g}$ of the total protein lacking in the knockout brain (Figure 4A, Supplementary Figure S2). In contrast, no specific signals were obtained in atrial lysates, including fat tissue and cardiac neurons, as well as in ventricular lysates (Figure 4A), while Western blot analysis for $\mathrm{HCN} 4$ detected a weak band at approx. $130 \mathrm{kDa}$ in wild-type and TRIP8b-deficient animals (Figure 4B). This was verified using a different TRIP8b antibody (Alomone Labs, Jerusalem, Israel) with the same result.

A

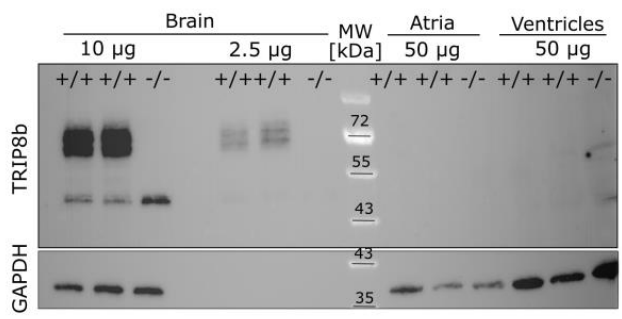

B
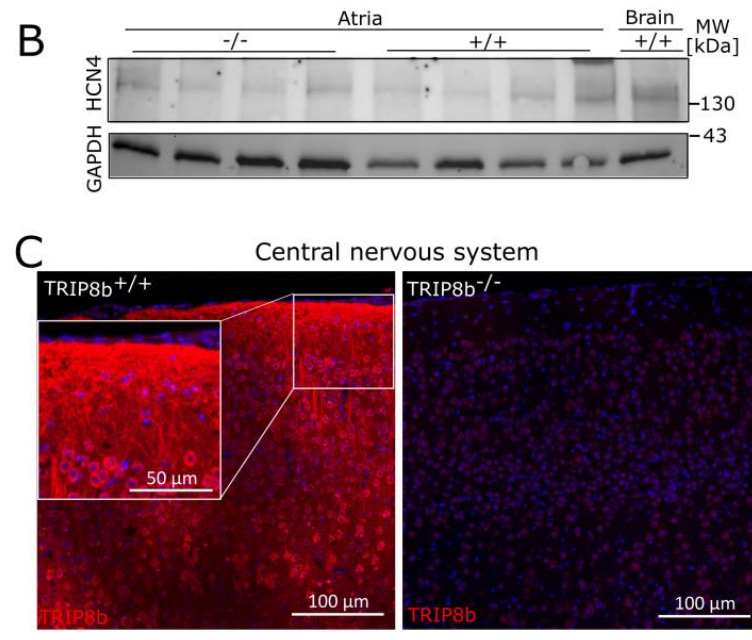

Central nervous system

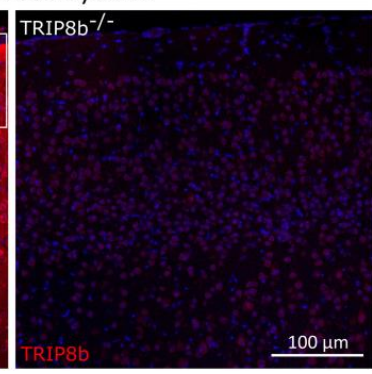

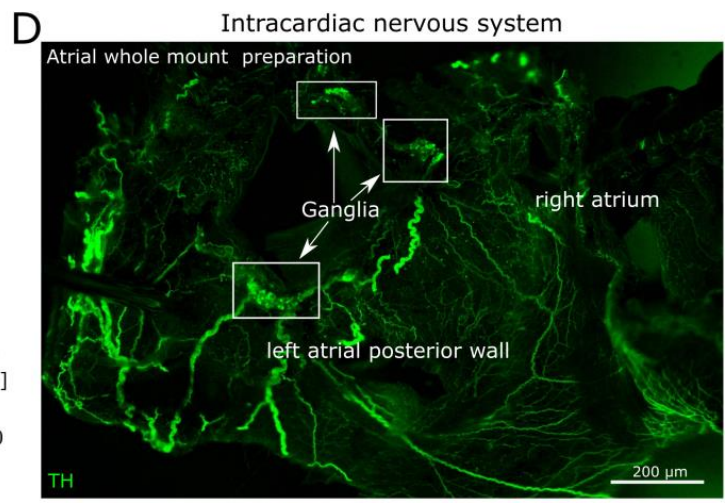

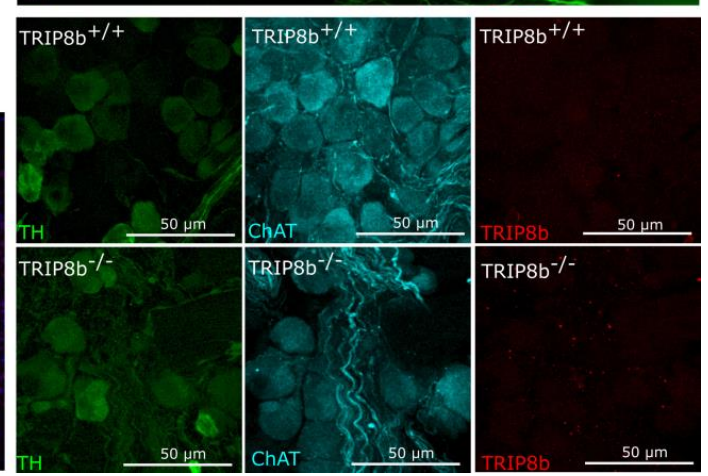

Figure 4. TRIP8b protein is not detectable in the atrial lysates and the cardiac autonomic nervous system. (A) Western blot analysis of brain tissue as positive control detects specific bands for TRIP8b (NBP2-38840, Novusbio) already at $2.5 \mu \mathrm{g}$ total protein. For the heart, $50 \mu \mathrm{g}$ atrial or ventricular lysate did not show any specific bands, while HCN4 (B) is detectable in both genotypes. (C) Immunohistochemistry for TRIP8b (APR-070, Alomone Labs) on paraffin sections was established in the central nervous system, more specifically, the cerebral cortex. Neurons positive for TRIP8b are detectable in the wild-type animals but not cortex of TRIP8b-deficient animals. (D) To increase the sensitivity of detection, atrial whole-mount preparations (upper panel shows exemplary staining with $\alpha \mathrm{TH}$ ab152, Merck Millipore) were stained and ganglia cut out for confocal microscopy (bottom panel with $\alpha \mathrm{TH}$ ab76442, Abcam). No specific signal was obtained for TRIP8b (APR-070, Alomone Labs), and no differences were detectable between the genotypes. 
Therefore, we established TRIP8b immunohistological staining on paraffin sections in the wild-type brain, which showed distinct expression patterns in the cerebral cortex, as expected (Figure 4C). Still, no specific staining was obtained in cardiac ganglia on paraffin sections; therefore, we performed whole-mount staining of atrial preparations (Figure 4D, upper panel) and dissected complete cardiac ganglia under a fluorescence binocular for subsequent confocal microscopy to increase the sensitivity of detection. Still, neither did we detect any TRIP8b staining beyond the background, nor did the staining differ between cardiac ganglia of wild-type and TRIP8b-deficient mice (Figure 4D, bottom panel). In line with this, no specific signal was obtained in the working myocardium, as well as sinus node (Figure 5, upper panel) and AV node of both genotypes (Figure 5, lower panel).
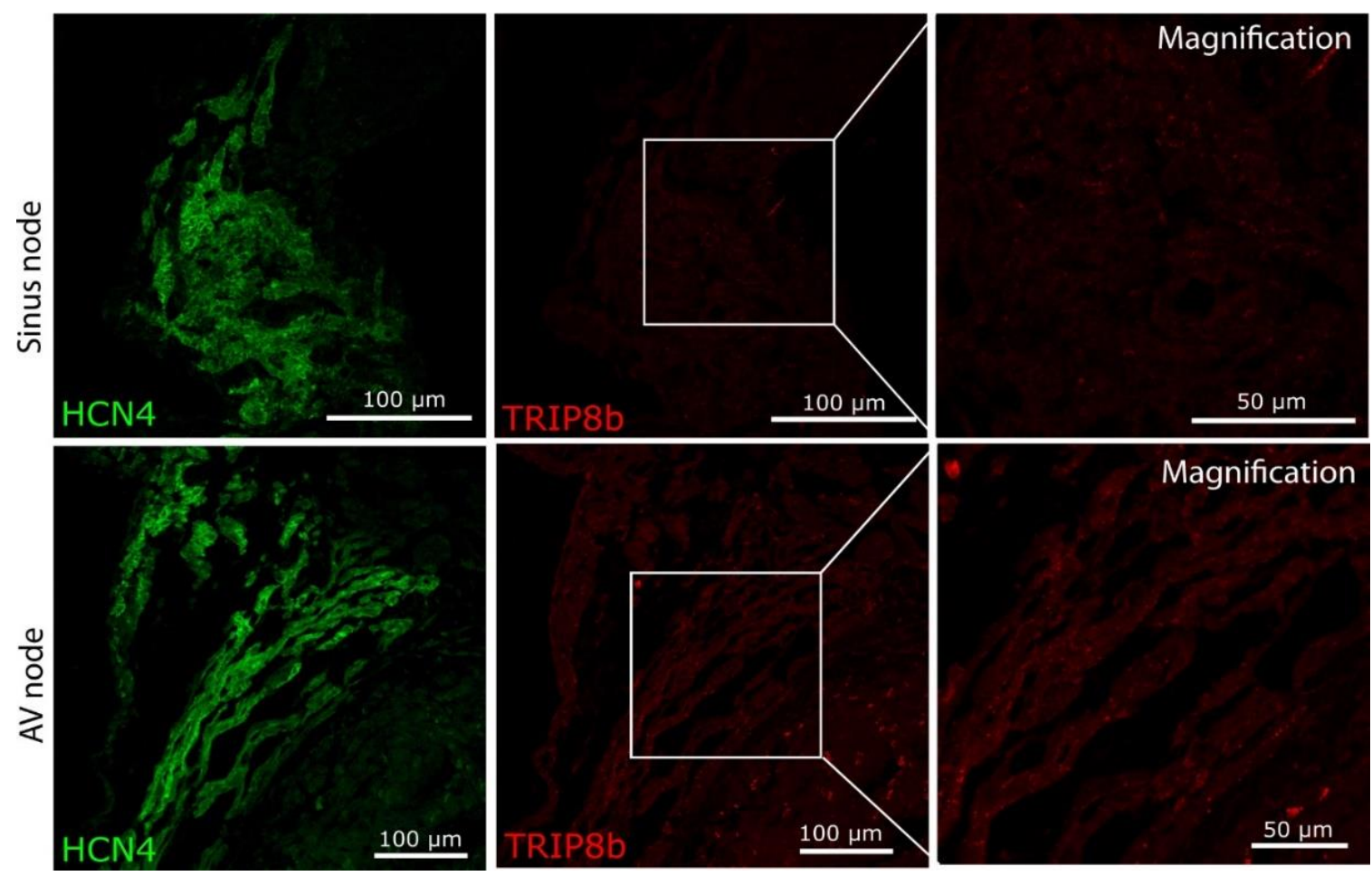

Figure 5. TRIP8b protein is not detectable in the cardiac conduction system in wild-type mice. Sinus node (upper panel) and atrioventricular node (AV node, bottom panel) were identified by anatomical landmarks and HCN4 staining (green). No staining for TRIP8b (red, APR-070, Alomone Labs) was detectable beyond the background.

\subsection{HCN Channel Expression Analysis in Cardiac Ganglia}

Since the main known function of TRIP8b to date is the modulation of HCN channels by affecting gating properties of HCN2 and HCN4 by limiting cAMP-induced activation [3], we studied the expression of Hcn 2 and Hcn 4 in intracardiac ganglia. In situ hybridization on paraffin sections showed that both mRNAs are present in ganglia of wild-type mice (Figure 6A). Gene expression of Hcn2 and Hcn 4 normalized to Cdkn1b, measured by quantitative PCR in ICNS lysates, did not differ between the genotypes (Figure 6B; Hcn2: $0.06 \pm 0.01$ wild type vs. $0.07 \pm 0.02$ knockout; $n=6$ per genotype; $p=0.9371$; data compared with Mann-Whitney test; Hcn4: $0.03 \pm 0.01$ wild type vs. $0.02 \pm 0.002$ knockout; $n=6$ per genotype; $p=0.3095$; data compared with Mann-Whitney test). This indicates that the electrophysiological phenotype of TRIP8b-deficient mice is most likely not attributable to changes in HCN expression levels. 

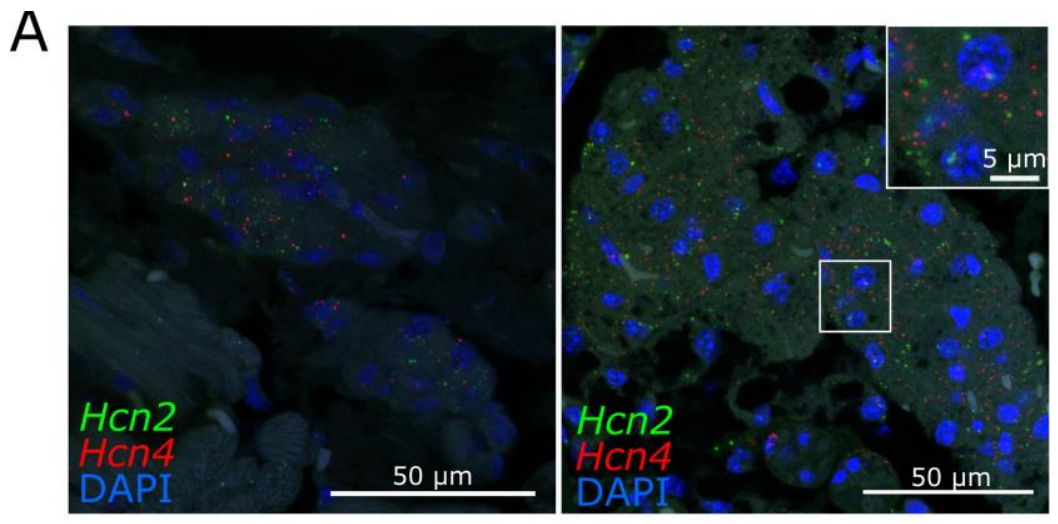

B
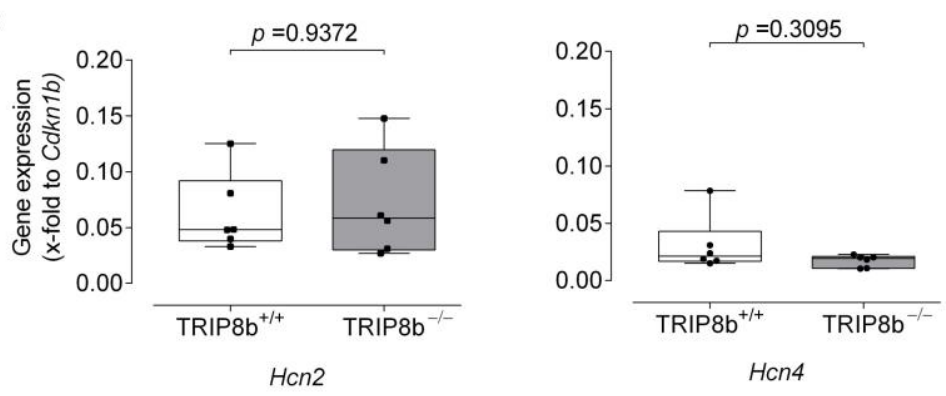

Figure 6. HCN channel expression in intracardiac ganglia. (A) In situ hybridization of two exemplary wild-type ganglia for Hcn2 (green) and Hcn4 (red). Both mRNAs are present within the ganglia. Boxed area is magnified in the inlay. (B) Gene expression analysis of Hcn 2 and Hcn4 in TRIP8bdeficient mice and wild-type littermates. Data are presented as normalized gene expression to $C d k n 1 b$ using the formula $2^{-\Delta \mathrm{Ct}}$ (box plots, minimum to maximum, $n=6$ per genotype) and were compared using Mann-Whitney test.

\section{Discussion}

The ICNS is important for the modulation of cardiac electrophysiology, and the HCN current $I_{\mathrm{f}}$ has been recorded in cardiac neurons of guinea pigs $[13,14]$. TRIP8 $\mathrm{b}$ is an interaction partner for $\mathrm{HCN}$ channels [6] and an auxiliary subunit that, upon assembly with HCN2 and HCN4, limits their activation by cAMP $[3,21,22]$. Here, we studied the expression and function of the HCN channel auxiliary subunit TRIP8b in the ICNS. Our main results are (1) TRIP8b-deficient mouse hearts show changes in atrial electrophysiology but not in sino-nodal function. (2) Trip $8 b$ mRNA is reliably detected in neuronal somata and fibers of the ICNS and, sparsely, in the sinus node and the AV node, most likely in nerve fibers within this region. Taken together, our experiments suggest a role of TRIP8b in the modulation of atrial electrophysiology that is beyond HCN-mediated sino-nodal control of the heart.

Modulation of cardiac electrophysiology has already been shown for other auxiliary subunits of HCN channels, such as vesicle-associated membrane protein (VAMP)associated protein B (VAPB/ERG30) [23]. Still, VAPB is expressed in the working myocardium, which is not the case for TRIP8b, according to the state of literature [6] and our own findings. In good agreement, no structural abnormalities such as myocardial alterations or remodeling were detectable in hearts from TRIP8b-deficient mice, which could have been a potential explanation for electrophysiological changes [24]. Electrophysiological characterization of TRIP8b-deficient mice in our study demonstrated increased ARP and AVNRP, but no changes in sino-nodal conduction, heart rate, or other common electrophysiological parameters connected to changes in the cholinergic system [19], compared to wild-type littermates. It is surprising that we observed an effect in $\mathrm{AV}$-nodal but not in sino-nodal conduction, but it was shown before that HCN channel inhibition influences the AV node much more than the sinus node, even though a higher amount of HCN4 channels 
are expressed in the latter [25]. Neurons of the ICNS have been shown to modify atrial and ventricular refractory periods directly $[19,26]$. A modulation of membrane resting potential and firing patterns by $\mathrm{HCN}$ channels has been described in other peripheral neurons, e.g., for HCN2 [15], which we show to be present in the ICNS as well. It could be speculated that the loss of TRIP8b leads to changes in neuronal firing, thereby affecting ARP via the ICNS without changing sino-nodal activity. The Langendorff model was shown to be well suited for studies of the intracardiac nervous system $[19,27,28]$. Indeed, the ICNS is embedded in autonomic reflex circuits, which can only be studied in vivo, thus limiting our conclusions.

We detected Trip $8 b$ mRNA in the ICNS via quantitative PCR and in situ hybridization. Santoro et al. have shown that Trip $8 b$ mRNA was not present in the heart [6], but these analyses were performed via Northern blotting, most likely of whole hearts, and did therefore contain only a little or no parts of the ICNS, which is located in epicardial fat tissue surrounding the atria. We were able to identify neuronal somata and nerve fibers of the ICNS as the origin of Trip $8 b$ mRNA. Additionally, a very low amount of mRNAs was found in the sinus node and AV node. Since both sinus and AV nodes are highly innervated by the autonomic nervous system [20], it is very likely that the observed Trip $8 b$ signal instead derives from single fine nerve fibers in this region. Of note is that, while exons 6-7 were lacking, transcripts from exons 8-9, 9-10, and 13-14 of Trip8b were detectable in knockout ICNS, indicating that splicing across the deletion took place. This also explains why RNAscope detects Trip $8 b$ also in TRIP8b-deficient animals since the employed technique typically uses approx. 20 different probes covering a region of one $\mathrm{kb}$ on the RNA molecule [29]. While these transcripts might lead to the generation of truncated protein forms, this was negated by Lewis et al. using antibodies against the Nand C-terminus of TRIP8b [4].

We were able to detect TRIP8b protein in the brain by Western blotting and immunohistochemistry, both in alignment with the literature $[4,6]$. As cardiac neurons account for only approximately 1000 cells in the mouse heart [10], expression of TRIP8b in the ICNS might be insufficient for detection by Western blotting. Still, even though immunohistological staining of TRIP8b in the brain gave reproducible results, TRIP8b was neither detectable in intracardiac ganglia nor in nerves, sinus node, AV node, or atrial or ventricular working myocardium, suggesting that the antibodies might be insufficient. It could also be speculated that TRIP8b protein is downregulated in the healthy heart and upregulated under (pathophysiological) circumstances or as needed, as was shown for the expression—and subsequent functional activity—of HCN channels in autonomic ganglia in diabetic mice [30]. However, evaluating whether Trip $8 b$ mRNA in the ICNS is detectable in a disease setting or in other autonomic ganglia was beyond the scope of this study.

Parasympathetic activation is highly relevant for atrial electrophysiology; in general, it shortens ARP and thereby increases the risk for atrial arrhythmias [31,32]. The higher ARP observed in TRIP8b-deficient animals might therefore present a potential anti-arrhythmic mechanism. Still, since no protein was found in the ICNS of wild-type mice that could explain this phenotype in the knockout. As cardiac autonomic control (sympathetic and parasympathetic) is conveyed from the brainstem [8], it could also be hypothesized that extracardiac reflex circuits in form of changes in neurotransmitter levels or differentially expressed proteins may be responsible for changes in atrial electrophysiology of TRIP8bdeficient mice. Susceptibility to AF did not differ between the genotypes, but this might be due to the fact that healthy mice are not prone to arrhythmias and thus the number of successful inductions was low in our study. A potential influence of TRIP8b on arrhythmia susceptibility should be tested in mice with an increased risk [33].

In conclusion, our study suggests a role of TRIP8b in the modulation of atrial electrophysiology beyond sino-nodal control. 


\section{Materials and Methods}

\subsection{TRIP8b-Deficient Mice}

$\mathrm{TRIP} \mathrm{b}^{-/-}$mice $(\mathrm{C} 57 \mathrm{Bl} / 6 \mathrm{~J})$ originally derived from Lewis et al. were graciously provided from Prof. Dr. Budde, Westfälische Wilhelms-Universität Münster and genotyped as described [4]. All experiments were performed in accordance with the Guide for the Care and Use of Laboratory Animals published by the US National Research Council Committee (8th edition, updated 2011) and approved by the regional regulatory authorities.

\subsection{Langendorff Perfusion}

Langendorff experiments and electrophysiological characterization using programmed stimulation were performed with male TRIP8 $\mathrm{b}^{-1-}$ mice and respective wild-type littermates (14-22 weeks), as described previously [19]. Mice were anesthetized by inhalation of isoflurane (Forane, Abbott Laboratories, Hannover, Germany 3-5\%). Adequate anesthesia was verified by loss of pedal withdrawal reflex before mice were euthanized via cervical dislocation. Hearts were excised and prepared for perfusion with modified Krebs-Henseleit solution: $119 \mathrm{mM} \mathrm{NaCl}, 25 \mathrm{mM} \mathrm{NaHCO} 3,4.6 \mathrm{mM} \mathrm{KCl}, 1.2 \mathrm{mM} \mathrm{KH}_{2} \mathrm{PO}_{4}, 1.1 \mathrm{mM} \mathrm{MgSO}_{4}$, $2.5 \mathrm{mM} \mathrm{CaCl}_{2}, 8.3 \mathrm{mM}$ glucose, and $2 \mathrm{mM}$ Na pyruvate; $\mathrm{pH} 7.4,95 \% \mathrm{O} 2 / 5 \% \mathrm{CO}_{2}$. A $2 \mathrm{~F}$ octapolar electrophysiology catheter (CIB'ER Mouse, NuMED Inc., Cross Roads, TX, USA) was inserted into the right ventricle for electrical stimulation with a cycle length of 100 $\mathrm{ms}$ for the initial 20-min equilibration period. $0.5 \mathrm{mM}$ hexamethonium (Sigma-Aldrich, St. Louis, MO, USA), a nicotinic antagonist, was added to the perfusion buffer before equilibration to block the activity of the intracardiac ganglia.

\subsection{In Vitro Electrophysiological Study}

Programmed stimulation was applied using a designated digital stimulus generator (STG4002, Multi-Channel Systems, Reutlingen, Germany) at twice the atrial or ventricular pacing threshold to obtain standard electrophysiological parameters [19,34].

Atrial (ARP) and ventricular refractory periods (VRP) were determined as the longest extrastimulus cycle length with an absent atrial or ventricular response (12 stimuli; S1S1: $100 \mathrm{~ms}$; one short-coupled extrastimulus with a $2 \mathrm{~ms}$ stepwise S1S2 reduction). Atrioventricular-nodal refractory period (AVNRP) was determined as longest extrastimulus cycle length with loss of AV-nodal conduction (12 stimuli; S1S1: $100 \mathrm{~ms}$; one short-coupled extrastimulus with a $2 \mathrm{~ms}$ stepwise S1S2 reduction), Wenckebach periodicity (WBP) as the longest S1S1 cycle length with loss of 1:1 AV-nodal conduction (8 stimuli; S1S1: 100 ms; 2 ms stepwise reduction). Sinus node recovery time (SNRT) was determined as the maximum return cycle length after $10 \mathrm{~s}$ of fixed-rate pacing at an S1S1 cycle length of $120 \mathrm{~ms}, 100 \mathrm{~ms}$, and $80 \mathrm{~ms}$. Rate-corrected SNRT (cSNRT) was calculated by subtracting the sinus cycle length from SNRT. For induction of atrial arrhythmias, burst stimulation was performed with twice the atrial pacing threshold according to Schrickel et al. (5 s at S1S1: 50-10 ms, 10 ms stepwise reduction) [35,36]. Atrial fibrillation (AF) was defined as rapid atrial electrogram for more than $1 \mathrm{~s}$.

\subsection{Histology and Immunohistochemistry}

Langendorff-perfused hearts were formalin-fixed for $24-48 \mathrm{~h}$ at RT, dehydrated, paraffin-embedded, and cut into $4 \mu \mathrm{m}$ sections for all subsequent experiments. Sections were deparaffinized and rehydrated. Hematoxylin-eosin (H\&E) was used for the detection of cardiac ganglia. Picrosirius red staining for visualization of fibrosis was performed using reagents from Polysciences Inc. (Warrington, PA, USA) according to the manufacturer's instructions. Immunohistological staining was performed, as described in detail previously [19,37]. Briefly, heat-induced antigen retrieval was performed with citrate buffer $(\mathrm{pH} 6)$ in a pressure cooker followed by treatment with $0.25 \%$ Sudan black $/ 70 \%$ ethanol for $30 \mathrm{~min}$ for quenching of autofluorescence. Sections were permeabilized $(0.2 \%$ Triton X-100/ tris-buffered saline (TBS) for $10 \mathrm{~min}$ ) and blocked (3\% bovine serum albumin (BSA)/TBS for $1 \mathrm{~h}$ at RT) before primary antibody (Supplementary Table S2) incubation overnight 
at $4{ }^{\circ} \mathrm{C}$ in $1 \%$ BSA/TBS. After three TBS washes for $10 \mathrm{~min}$ each, secondary antibodies (Supplementary Table S3) were incubated for $2 \mathrm{~h}$ at RT in TBS. Slides were mounted in DAPI Fluoromount-G (SouthernBiotech, Birmingham, AL, USA). Brains were embedded in $5 \%$ agarose/PBS and sagitally cut at $30 \mu \mathrm{m}$ using a vibratome.

\subsection{Staining of Murine Atria and Vibratome Sections}

Staining of intracardiac ganglia from atrial whole-mount preparations was adapted from previous protocols [19]. Even though cardiac ganglia are parasympathetic, they express tyrosine hydroxylase in a subset of neurons $[19,38]$ which was used for identification due to the strong staining. Ganglia-containing fat pads were dissected from Langendorffperfused and formalin-fixed hearts using fine forceps. Lung, esophagus, and trachea were removed and specimens stored in phosphate-buffered saline (PBS) at $4{ }^{\circ} \mathrm{C}$. Brains were formalin-fixed for $48 \mathrm{~h}$ at room temperature, embedded in 5\% agarose/PBS, and cut into $30 \mu \mathrm{m}$ sagittal sections using a vibratome.

For immunohistological staining, incubation steps were performed in 96-well plates. Specimens were bleached in Dent's bleach (MeOH:DMSO: $\mathrm{H}_{2} \mathrm{O}_{2}$ 4:1:1) [39] 2-12 $\mathrm{h}$ at $4{ }^{\circ} \mathrm{C}$, rehydrated in a descending methanol series, and subsequently permeabilized by incubation $2 \times 1 \mathrm{~h}$ in $1 \%$ Triton X-100 in PBS at RT. To decrease autofluorescence, Sudan black $(0.25 \%$ in $70 \%$ ethanol) staining was performed for $2 \mathrm{~h}$ at RT. Atrial preparations were blocked overnight at $4{ }^{\circ} \mathrm{C}(5 \%$ BSA / PBS $0.1 \%$ Triton X-100). Primary antibodies (Supplementary Table S1) were incubated in a blocking buffer for $96 \mathrm{~h}$ at $4{ }^{\circ} \mathrm{C}$. Specimens were washed $3 \times 1 \mathrm{~h}$ in $0.1 \%$ Triton X-100/PBS. Incubation of secondary antibodies was performed in $0.1 \%$ Triton X-100/PBS for $48 \mathrm{~h}$ at $4{ }^{\circ} \mathrm{C}$. Afterward, samples were washed for $6 \times 30 \mathrm{~min}$ in $0.1 \%$ Triton X-100/PBS. Vibratome sections were mounted in DAPI Fluoromount, while atria were stored in PBS at $4{ }^{\circ} \mathrm{C}$.

\subsection{RNAscope In Situ Hybridization}

RNAscope in situ hybridization assay [29] was carried out for detection of Trip8b/Pex5l, Hcn2, and Hcn4 mRNA on paraffin sections using RNAscope 2.5 HD detection kit (\#322310; Advanced Cell Diagnostics (ACD), Newark, CA, USA) for chromogenic staining and RNAscope Multiplex Fluorescent v2 reagent kit (\#323100, ACD, Newark, CA, USA) for fluorescent staining following the manufacturer's instructions. In brief, sections were deparaffinized by incubation at $60{ }^{\circ} \mathrm{C}$ for $1 \mathrm{~h}$ in xylene replacement (HS200-5, SigmaAldrich St. Louis, MO, USA) and 100\% ethanol, followed by 10 min hydrogen peroxide incubation to quench internal peroxidase activity and $10 \mathrm{~min}$ target retrieval at $95^{\circ} \mathrm{C}$. In addition, protease plus treatment at $40^{\circ} \mathrm{C}$ for $30 \mathrm{~min}$ was performed to permeabilize tissue sections. The probe (RNAscope Mm-Pex51 \#551531; Mm-Hcn4 \#421271; Mm-Hcn2-C2 $\# 427001-\mathrm{C} 2, \mathrm{ACD}$ ) was hybridized for $2 \mathrm{~h}$ at $40^{\circ} \mathrm{C}$, followed by RNAscope amplification steps. In the case of chromogenic staining 3,3'-diaminobenzidine and hematoxylin were used for visualization of staining and cell nucleus, respectively. Slides stained with the fluorescent RNAscope kit were mounted in DAPI Fluoromount-G for nucleus staining.

\subsection{Microscopy}

Confocal images were generated using a Leica TCS SP5 confocal microscope (Leica Microsystems $\mathrm{GmbH}$, Wetzlar, Germany) with $\times 10$ numerical aperture (NA) $=0.3 \mathrm{HC}$ PL Fluotar, $\times 20 \mathrm{NA}=0.7 \mathrm{HC}$ PL APO CS Imm/Corr oil, and $\times 40$ NA $=1.3 \mathrm{HCX}$ PL APO CS objectives. Three-dimensional images were collected over the full range of the signal, and a maximum projection image was created using the Leica LAS AF software. A Keyence digital microscope was used to image chromogenic sections (plan apo $\times 10 \mathrm{NA}=0.45$ and plan apo $\times 60 \mathrm{NA}=1.40$ oil objectives). The atrial whole mount was imaged using an SMZ25 stereomicroscope (Nikon, Tokyo, Japan). 


\section{8. mRNA Quantification}

For mRNA quantification, the QuPath software, version 0.2.3 [40] was used on fluorescent RNAscope maximum z projection confocal images comprised of approx. five focal planes with a stack size of $0.5 \mu \mathrm{m}$ adapted from Merritt et al. [41]. The regions of interest (ROI: ICNS [nerves and ganglia], sinus node, and AV node) were marked with the freehand tool to quantify the number of cells (nuclei, based on DAPI staining) and the number of spots per cell was computated by the software. As reported by Merritt et al., nucleus detection was not reliable in all cases; therefore, nuclei bigger than double standard deviation were excluded from the analysis. Due to differences in tissue composition, settings used for the detection of nuclei were set for each ROI differently, while detection of RNAscope signals was identical. The following settings were used for detection of nuclei: 'requested pixel size': 0.5; 'background radius': 8.0 (ICNS), 10 (sinus node), 8.0 (AV node); 'median radius': 0.0; 'sigma': 1.5; 'minimum area': 10.0; 'maximum area': 400.0; 'threshold': 25.0 (ICNS), 10.0 (sinus node) 10.0 (AV node); 'split by shape': true 'cell expansion': 5.0 (ICNS), 10.0 (sinus node), 5.0 (AV node); 'include cell nucleus': true; 'smooth boundaries': true; 'make measurements': true. RNAscope spot detection was performed with the following settings: 'detection [Channel]': 35.0; 'Smooth before detection: true; 'split by intensity': true; 'split by shape': true; 'expected spot Size': 1.0; 'min spot size': 0.2; 'max spot size': 1.0; 'include clusters': true.

\subsection{Western Blot Analysis}

To study TRIP8b protein expression, Western blot analysis of cardiac tissue was performed with the brain as positive control [19]. Hearts were dissected as described above and atria, as well as ventricles, shock frozen in liquid nitrogen. Frozen tissues were ground using mortar and pestle. Powdered tissue was lysed in RIPA buffer $(50 \mathrm{mM}$ Tris base $\mathrm{pH}$ 8.0, $150 \mathrm{mM}$ sodium chloride, $0.5 \%$ sodium deoxycholate, $0.1 \%$ sodium dodecyl sulfate, $1 \%$ Triton X-100, $1 \mathrm{mM}$ dithiothreitol, plus protease inhibitors (Complete Mini, Roche Roche Life Science, Basel, Switzerland) for $1 \mathrm{~h}$ at ice and centrifuged for $30 \mathrm{~min}$ at $15.000 \mathrm{~g}, 4^{\circ} \mathrm{C}$. Protein concentrations were quantified using the Pierce BCA Protein Assay Kit (ThermoFisher Scientific, Waltham, MA, USA) according to the manufacturer's instructions.

Proteins were separated under denaturing conditions by sodium dodecyl sulfatepolyacrylamide gels (SDS-PAGE) using 10\% acrylamide gels and transferred to nitrocellulose membranes via semidry blotting using the Trans-Blot Turbo Transfer System (Bio-Rad, Hercules, CA, USA). The membranes were blocked in 5\% skim milk powder in TBS and incubated overnight at $4{ }^{\circ} \mathrm{C}$ with primary antibody (Supplementary Table S1). After three washing steps with TBS/0.5\% Tween, a secondary antibody (Supplementary Table S2) was incubated for one hour at room temperature. The Fusion Solo $S$ gel documentation system (VRW International, Radnor, PA, USA) was used to detect reactive protein bands with enhanced chemiluminescence (Super Signal West Femto, Thermo Fisher Scientific, Waltham, MA, USA).

\subsection{Gene Expression Analyses}

Tissue samples were snap frozen and lysed with QIAzol lysis reagent in a TissueLyser II (Qiagen, Hilden, Germany). RNA was extracted using the RNeasy mini kit (Qiagen, Hilden, Germany) following the manufacturer's protocol, as described previously [19]. DNAse I treatment for $1 \mathrm{~h}$ was performed to avoid DNA contamination. RNA concentration was measured with the help of Nanodrop 2000c (ThermoFisher Scientific, Waltham, MA, USA), and RNA was stored at $-80{ }^{\circ} \mathrm{C}$ until later usage. For reverse RNA transcription using the high capacity cDNAse kit (ThermoFisher Scientific, Waltham, MA, USA) $250 \mathrm{ng}$ of total RNA was used. Generated cDNA was diluted to a working concentration of $2.5 \mathrm{ng} / \mu \mathrm{L}$. For gene expression analyses real-time PCR was performed using $4 \mu \mathrm{L}$ cDNA template, $5 \mu \mathrm{L}$ gene expression master mix (ThermoFisher Scientific, Waltham, MA, USA), and $0.5 \mu \mathrm{L}$ gene expression assay (Life Technologies) in a QuantStudio 7 Flex, Applied Biosystems (ThermoFisher Scientific, Waltham, MA, USA). Gene expression assays, 
containing forward and reverse primers and FAM-labelled probe, are listed in Supplementary Table S4. Measurements were performed in duplicates. Gene expression was compared by normalizing the gene expression to the endogenous control $C d k n 1 b$ using the formula $2^{-\Delta \mathrm{Ct}}$.

\subsection{Statistical Analyses}

All values are described in mean \pm standard error of the mean (SEM) if not stated otherwise. Data were tested for normality using the D'Agostino-Pearson omnibus test. Student's $t$-test was used for comparisons of normally distributed data. Nonparametric tests were chosen for differences across groups with not normally distributed data. $p$ values $<0.05$ were considered statistically significant. Statistical analysis was performed using GraphPad Prism 6.07 (GraphPad Software, San Diego, CA, USA).

Supplementary Materials: The following is available online at https:/ /www.mdpi.com/article/10 $.3390 /$ ijms22094772/s1.

Author Contributions: Conceptualization, K.S., N.E., N.K., and C.M.; methodology, K.S., H.B., A.M., N.E., E.A., C.J., U.P., and D.L.; formal analysis, K.S., H.B., and A.M.; investigation, K.S., H.B., A.M., N.E., E.A., C.J., U.P., and D.L.; resources, D.M.C.; writing-original draft preparation, K.S. and H.B.; writing-review and editing, N.K. and C.M.; funding acquisition, K.S., N.E., N.K., and C.M. All authors have read and agreed to the published version of the manuscript.

Funding: This work was supported by the German Centre for Cardiovascular Research (DZHK) [81X2710149 to C.M, K.S., N.K., and N.E.].

Institutional Review Board Statement: All experiments were performed in accordance with the Guide for the Care and Use of Laboratory Animals published by the US National Research Council Committee (8th edition, updated 2011) and approved (ORG_732,01/2017; ORG_847,07/2017) by the regional regulatory authorities.

Informed Consent Statement: Not applicable.

Data Availability Statement: Not applicable.

Acknowledgments: The authors kindly thank Thomas Budde, University Clinic Münster for providing TRIP8b-deficient mice, the UKE microscopy imaging facility [Umif], University Hospital Hamburg-Eppendorf, Hartwig Wieboldt for excellent technical support, and Christian Börnchen and Christoph Hamers from the Nikon Centre of Excellence for providing the SMZ25 stereomicroscope and support.

Conflicts of Interest: The authors declare no conflict of interest.

\section{References}

1. Herrmann, S.; Schnorr, S.; Ludwig, A. HCN Channels-Modulators of Cardiac and Neuronal Excitability. Int. J. Mol. Sci. 2015, 16, 1429-1447. [CrossRef] [PubMed]

2. Baruscotti, M.; Barbuti, A.; Bucchi, A. The cardiac pacemaker current. J. Mol. Cell. Cardiol. 2010, 48, 55-64. [CrossRef]

3. Zolles, G.; Wenzel, D.; Bildl, W.; Schulte, U.; Hofmann, A.; Müller, C.S.; Thumfart, J.-O.; Vlachos, A.; Deller, T.; Pfeifer, A.; et al. Association with the Auxiliary Subunit PEX5R/Trip8b Controls Responsiveness of HCN Channels to cAMP and Adrenergic Stimulation. Neuron 2009, 62, 814-825. [CrossRef] [PubMed]

4. Lewis, A.S.; Vaidya, S.P.; Blaiss, C.A.; Liu, Z.; Stoub, T.R.; Brager, H.; Chen, X.; Bender, R.A.; Estep, C.M.; Popov, A.B.; et al. Deletion of the HCN channel auxiliary subunit TRIP8b impairs hippocampal Ih localization and function and promotes antidepressant behavior in mice. J. Neurosci. 2011, 31, 7424-7440. [CrossRef]

5. Piskorowski, R.; Santoro, B.; Siegelbaum, S.A. TRIP8b Splice Forms Act in Concert to Regulate the Localization and Expression of HCN1 Channels in CA1 Pyramidal Neurons. Neuron 2011, 70, 495-509. [CrossRef] [PubMed]

6. Santoro, B.; Wainger, B.J.; Siegelbaum, S.A. Regulation of HCN Channel Surface Expression by a Novel C-Terminal Protein-Protein Interaction. J. Neurosci. 2004, 24, 10750-10762. [CrossRef]

7. Saponaro, A.; Cantini, F.; Porro, A.; Bucchi, A.; DiFrancesco, D.; Maione, V.; Donadoni, C.; Introini, B.; Mesirca, P.; Mangoni, M.E.; et al. A synthetic peptide that prevents cAMP regulation in mammalian hyperpolarization-activated cyclic nucleotide-gated (HCN) channels. eLife 2018, 7, 085201. [CrossRef]

8. Ardell, J.L.; Armour, J.A. Neurocardiology: Structure-Based Function. Compr. Physiol. 2016, 6, 1635-1653. [CrossRef] [PubMed] 
9. Campos, I.D.; Pinto, V.; Sousa, N.; Pereira, V.H. A brain within the heart: A review on the intracardiac nervous system. J. Mol. Cell. Cardiol. 2018, 119, 1-9. [CrossRef] [PubMed]

10. Rysevaite, K.; Saburkina, I.; Pauziene, N.; Vaitkevicius, R.; Noujaim, S.F.; Jalife, J.; Pauza, D.H. Immunohistochemical characterization of the intrinsic cardiac neural plexus in whole-mount mouse heart preparations. Hear. Rhythm. 2011, 8, 731-738. [CrossRef]

11. Pauza, D.H.; Skripka, V.; Pauziene, N.; Stropus, R. Morphology, distribution, and variability of the epicardiac neural ganglionated subplexuses in the human heart. Anat. Record 2000, 259, 353-382. [CrossRef]

12. Armour, J.A. Cardiac neuronal hierarchy in health and disease. Am. J. Physiol. Integr. Comp. Physiol. 2004, 287, R262-R271. [CrossRef] [PubMed]

13. Tompkins, J.D.; Lawrence, Y.T.; Parsons, R.L. Enhancement of Ih, but not inhibition of IM, is a key mechanism underlying the PACAP-induced increase in excitability of guinea pig intrinsic cardiac neurons. Am. J. Physiol. Integr. Comp. Physiol. 2009, 297, R52-R59. [CrossRef] [PubMed]

14. Merriam, L.A.; Barstow, K.L.; Parsons, R.L. Pituitary adenylate cyclase-activating polypeptide enhances the hyperpolarizationactivated nonselective cationic conductance, Ih, in dissociated guinea pig intracardiac neurons. Regul. Pept. 2004, 123, 123-133. [CrossRef]

15. Emery, E.C.; Young, G.T.; Berrocoso, E.M.; Chen, L.; McNaughton, P.A. HCN2 Ion Channels Play a Central Role in Inflammatory and Neuropathic Pain. Science 2011, 333, 1462-1466. [CrossRef]

16. E McGovern, A.; Robusto, J.; Rakoczy, J.; Simmons, D.G.; Phipps, S.; Mazzone, S.B. The effect of hyperpolarization-activated cyclic nucleotide-gated ion channel inhibitors on the vagal control of guinea pig airway smooth muscle tone. Br. J. Pharmacol. 2014, 171, 3633-3650. [CrossRef]

17. Kullmann, P.H.M.; Sikora, K.M.; Clark, K.L.; Arduini, I.; Springer, M.G.; Horn, J.P. HCN hyperpolarization-activated cation channels strengthen virtual nicotinic EPSPs and thereby elevate synaptic amplification in rat sympathetic neurons. J. Neurophysiol. 2016, 116, 438-447. [CrossRef] [PubMed]

18. Doan, T.N.; Stephans, K.; Ramirez, A.N.; Glazebrook, P.A.; Andresen, M.C.; Kunze, D.L. Differential Distribution and Function of Hyperpolarization-Activated Channels in Sensory Neurons and Mechanosensitive Fibers. J. Neurosci. 2004, 24, $3335-3343$. [CrossRef]

19. Jungen, C.; Scherschel, K.; Eickholt, C.; Kuklik, P.; Klatt, N.; Bork, N.; Salzbrunn, T.; Alken, F.; Angendohr, S.; Klene, C.; et al. Disruption of cardiac cholinergic neurons enhances susceptibility to ventricular arrhythmias. Nat. Commun. 2017, $8,14155$. [CrossRef] [PubMed]

20. Pauza, D.H.; Rysevaite, K.; Inokaitis, H.; Jokubauskas, M.; Pauza, A.G.; Brack, K.E.; Pauziene, N. Innervation of sinoatrial nodal cardiomyocytes in mouse. A combined approach using immunofluorescent and electron microscopy. J. Mol. Cell. Cardiol. 2014, 75, 188-197. [CrossRef]

21. Bankston, J.R.; DeBerg, H.A.; Stoll, S.; Zagotta, W.N. Mechanism for the inhibition of the cAMP dependence of HCN ion channels by the auxiliary subunit TRIP8b. J. Biol. Chem. 2017, 292, 17794-17803. [CrossRef]

22. Santoro, B.; Piskorowski, R.A.; Pian, P.; Hu, L.; Liu, H.; Siegelbaum, S.A. TRIP8b Splice Variants Form a Family of Auxiliary Subunits that Regulate Gating and Trafficking of HCN Channels in the Brain. Neuron 2009, 62, 802-813. [CrossRef]

23. Silbernagel, N.; Walecki, M.; Schäfer, M.K.-H.; Kessler, M.; Zobeiri, M.; Rinné, S.; Kiper, A.K.; Komadowski, M.A.; Vowinkel, K.S.; Wemhöner, K.; et al. The VAMP-associated protein VAPB is required for cardiac and neuronal pacemaker channel function. FASEB J. 2018, 32, 6159-6173. [CrossRef]

24. Lau, D.H.; Mackenzie, L.; Kelly, D.J.; Psaltis, P.J.; Worthington, M.; Rajendram, A.; Kelly, D.R.; Nelson, A.J.; Zhang, Y.; Kuklik, P.; et al. Short-term hypertension is associated with the development of atrial fibrillation substrate: A study in an ovine hypertensive model. Hear. Rhythm. 2010, 7, 396-404. [CrossRef] [PubMed]

25. Liu, J.; Noble, P.J.; Xiao, G.; Abdelrahman, M.; Dobrzynski, H.; Boyett, M.R.; Lei, M.; Noble, D. Role of pacemaking current in cardiac nodes: Insights from a comparative study of sinoatrial node and atrioventricular node. Prog. Biophys. Mol. Biol. 2008, 96, 294-304. [CrossRef]

26. Hou, Y.; Scherlag, B.J.; Lin, J.; Zhang, Y.; Lu, Z.; Truong, K.; Patterson, E.; Lazzara, R.; Jackman, W.M.; Po, S.S. Ganglionated Plexi Modulate Extrinsic Cardiac Autonomic Nerve Input. J. Am. Coll. Cardiol. 2007, 50, 61-68. [CrossRef] [PubMed]

27. Rajendran, P.S.; Challis, R.C.; Fowlkes, C.C.; Hanna, P.; Tompkins, J.D.; Jordan, M.C.; Hiyari, S.; Gabris-Weber, B.A.; Greenbaum, A.; Chan, K.Y.; et al. Identification of peripheral neural circuits that regulate heart rate using optogenetic and viral vector strategies. Nat. Commun. 2019, 10, 1-13. [CrossRef] [PubMed]

28. Brack, K.E.; Coote, J.H.; Ng, G.A. Vagus nerve stimulation protects against ventricular fibrillation independent of muscarinic receptor activation. Cardiovasc. Res. 2011, 91, 437-446. [CrossRef]

29. Wang, F.; Flanagan, J.; Su, N.; Wang, L.-C.; Bui, S.; Nielson, A.; Wu, X.; Vo, H.-T.; Ma, X.-J.; Luo, Y. RNAscope: A Novel in Situ RNA Analysis Platform for Formalin-Fixed, Paraffin-Embedded Tissues. J. Mol. Diagn. 2012, 14, 22-29. [CrossRef] [PubMed]

30. Tu, H.; Zhang, L.; Tran, T.; Muelleman, R.; Li, Y. Diabetes alters protein expression of hyperpolarization-activated cyclic nucleotide-gated channel subunits in rat nodose ganglion cells. Neuroscience 2010, 165, 39-52. [CrossRef]

31. Schauerte, P.; Scherlag, B.J.; Pitha, J.; Scherlag, M.A.; Reynolds, D.; Lazzara, R.; Jackman, W.M. Catheter Ablation of Cardiac Autonomic Nerves for Prevention of Vagal Atrial Fibrillation. Circulation 2000, 102, 2774-2780. [CrossRef] [PubMed] 
32. Nakagawa, H.; Scherlag, B.J.; Patterson, E.; Ikeda, A.; Lockwood, D.; Jackman, W.M. Pathophysiologic basis of autonomic ganglionated plexus ablation in patients with atrial fibrillation. Hear. Rhythm. 2009, 6, S26-S34. [CrossRef]

33. Nishida, K.; Michael, G.; Dobrev, D.; Nattel, S. Animal models for atrial fibrillation: Clinical insights and scientific opportunities. Europace 2009, 12, 160-172. [CrossRef]

34. Jungen, C.; Scherschel, K.; Bork, N.I.; Kuklik, P.; Eickholt, C.; Kniep, H.; Klatt, N.; Willems, S.; Nikolaev, V.O.; Meyer, C. Impact of Intracardiac Neurons on Cardiac Electrophysiology and Arrhythmogenesis in an Ex Vivo Langendorff System. J. Vis. Exp. 2018, e57617. [CrossRef] [PubMed]

35. Schrickel, J.W.; Stöckigt, F.; Krzyzak, W.; Paulin, D.; Li, Z.; Lübkemeier, I.; Fleischmann, B.; Sasse, P.; Linhart, M.; Lewalter, T.; et al Cardiac conduction disturbances and differential effects on atrial and ventricular electrophysiological properties in desmin deficient mice. J. Interv. Card. Electrophysiol. 2010, 28, 71-80. [CrossRef] [PubMed]

36. Schrickel, J.W.; Bielik, H.; Yang, A.; Schimpf, R.; Shlevkov, N.; Burkhardt, D.; Meyer, R.; Grohe, C.; Fink, K.; Tiemann, K.; et al. Induction of atrial fibrillation in mice by rapid transesophageal atrial pacing. Basic Res. Cardiol. 2002, 97, 452-460. [CrossRef] [PubMed]

37. Scherschel, K.; Hedenus, K.; Jungen, C.; Lemoine, M.D.; Rübsamen, N.; Veldkamp, M.W.; Klatt, N.; Lindner, D.; Westermann, D.; Casini, S.; et al. Cardiac glial cells release neurotrophic S100B upon catheter-based treatment of atrial fibrillation. Sci. Transl. Med. 2019, 11, eaav7770. [CrossRef]

38. Rysevaite, K.; Saburkina, I.; Pauziene, N.; Noujaim, S.F.; Jalife, J.; Pauza, D.H. Morphologic pattern of the intrinsic ganglionated nerve plexus in mouse heart. Hear. Rhythm. 2011, 8, 448-454. [CrossRef]

39. Dent, J.A.; Polson, A.G.; Klymkowsky, M.W. A whole-mount immunocytochemical analysis of the expression of the intermediate filament protein vimentin in Xenopus. Development 1989, 105, 61-74. [CrossRef]

40. Bankhead, P.; Loughrey, M.B.; Fernández, J.A.; Dombrowski, Y.; McArt, D.G.; Dunne, P.D.; McQuaid, S.; Gray, R.T.; Murray, L.J.; Coleman, H.G.; et al. QuPath: Open source software for digital pathology image analysis. Sci. Rep. 2017, 7, 16878. [CrossRef]

41. Merritt, C.R.; Ong, G.T.; Church, S.E.; Barker, K.; Danaher, P.; Geiss, G.; Hoang, M.; Jung, J.; Liang, Y.; McKay-Fleisch, J.; et al. Multiplex digital spatial profiling of proteins and RNA in fixed tissue. Nat. Biotechnol. 2020, 38, 586-599. [CrossRef] [PubMed] 